\title{
Attributes of Dispersing Meadow Voles in Open-Grid Populations
}

\author{
Raymond D. DUESER, Marcia L. WILSON \& Robert K. ROSE ${ }^{1}$
}

Dueser R. D., Wilson M. L. \& Rose R. K., 1981: Attributes of dispersing meadow voles in open-grid populations. Acta theriol., 26, 9: 139-162 [With 6 Tables \& 5 Figs.]

Dispersal was investigated in two open-grid populations of meadow voles, Microtus pennsylvanicus (Ord, 1815) in central Virginia (U.S.A.) from November 1974 to April 1978. "Dispersal" was defined as immigration onto open, occupied population grids. Dispersers were distinguished from residents by weight at first capture. Individuals first captured at weights $<30 \mathrm{~g}$ were classified as residents; those first captured at $\geqslant 30 \mathrm{~g}$ were classified as dispersers. Three independent lines of evidence support the validity of the $30 \mathrm{~g}$ criterion for recognizing dispersers in these vole populations. With frequent trapping and high trappability, particularly of young animals, this open-grid method of study offers two advantages in the study of dispersal. First, dispersers identified in this way exist in a biologically realistic environment as they move into or through an established population. Second, time-dependent components of the fitness of these dispersers can be monitored and compared with those of residents occupying the same habitat. Dispersers (immigrants) usually constituted $>75 \%$ of the minimum number of animals known to be alive in any week. Dispensal occurred continuously and was more important than in situ reproduction as a source of new individuals in the population. Using the criterion of a negative correlation between the proportion of the population dispersing (immigrating) and grid population density, dispersal was not positively density-dependent. Aithough sex ratios of residents did not differ from 1:1, those of dispersers favored males on both grids. Nevertheless, $42 \%$ of all dispersers were female. Dispersers differed from adult $(\geqslant 30 \mathrm{~g})$ residents in that they were (1) significantly heavier than adult residents of the same sex and (2) more often in reproductive condition, both at first capture and later. Thus, dispersers had the potential to contribute more offspring per individual than residents, Dispersers and adult residents had comparable lifespans on both grids. Females had longer lifespans than males. Based on these components of fitness, dispersers appeared to be comparable or superior to residents. The attributes of the dispersers and the apparent lack of densitydependence may be interpreted as evidence of pre-saturation dispersal in these populations.

[Dept. Environmental Sci. (RDD, MLW), and Dept. Biol. (RKR), Univ. Virginia, Charlottesville, Virginia 22903, U.S.A.]

1 Present address; Dept. Biol. Sci., Old Dominion Univ., Norfolk, Virginia 23508 , USA. 


\section{INTRODUCTION}

Natality and mortality have been regarded as the important demographic parameters in the dynamics of small mammal populations. Immigration and emigration usually have been assumed to cancel one another (Krebs, 1978a, p. 145), so that changes in the density of populations have been attributed primarily to variation in the rates of birth and death. Nevertheless, Howard (1960) and Lidicker (1962, 1975) hypothesized that dispersal might be an important factor in population regulation, and dispersal now occupies a central position in the geneticbehavioral hypothesis of population regulation (Chitty, 1960, 1967; Krebs et al., 1973; Krebs, 1978b). Although dispersal can be defined in terms of either immigration or emigration, field studies of rodent populations have focused on emigration. Several investigators have attempted to determine the losses from vole populations attributable to dispersal and have cornpared the reproductive and genetic attributes of dispersers and residents (Myers \& Krebs, 1971; Krebs et al., 1976; Tamarin, 1977; Gaines, Vivas \& Baker, 1979).

The principal method for identifying "dispersers" in vole populations has been called the "dispersal sink" technique by Lidicker (1975). As used by Myers \& Krebs (1971), Krebs et al., (1976) and Tamarin (1977), among others, immigrants captured on removal grids are treated as a random subset of all dispersing animals. Some proportion of these immigrants, usually less than $30 \%$, are tagged animals from nearby control grids. Consequently, although the dispersal sink method is intended to evaluate the genotype and quality of emigrants from the control grids, in fact usually $70 \%$ or more of these "dispersers" are immigrants of unknown origin.

In separate studies, Gaines et al. (1979), L. Verner and L. Riggs (personal communication) monitored the attributes of emigrants from enclosed vole populations. Animals were able to leave the enclosures through exit doors which were raised during periods of active trapping. The advantage of this system is that information on genotype, sex, body weight, and reproductive condition can be compared for non-dispersers and dispersers of known origin. However, the exit-door method prevents free dispersal except during trapping periods, and voles living on the margins of the enclosure may accidently fall into the disperser category.

We monitored dispersal of adult meadow voles, Microtus pennsylvanicus (Ord, 1815) onto open, occupied population grids. "Dispersers" were identified operationally on the basis of body weight at first capture. Just as the dispersal sink and exit-door methods have shortcomings, this method inevitably involves some risk of misclassification of residents as 
dispersers and vice versa. However, the open-grid method does offer two significant advantages. First, dispersers identified in this way exist in a biologically realistic environment as they move into or through an established population. Second, time-dependent components of the fitness of these dispersers, such as lifespan and reproductive activity, can be monitored and compared with those of adult residents occupying the same habitat. The dispersal sink and exit-door methods of study provide an instantaneous view of dispersal. Where it is applicable, the open-grid method provides both an instantaneous and a dynamic view of this process.

Using this open-grid approach, the specific objectives of this study were (1) to determine the numerical importance of dispersers to the vole population into which they immigrate, (2) to compare residents and dispersers for sex ratio, movement, and several components of individual fitness (adult lifespan, adult body weight, and reproductive condition), and (3) to evaluate the relative roles of "saturation" and "pre-saturation" dispersal (Lidicker, 1975) in vole population dynamics.

\section{STUDY AREA AND METHODS}

\section{Study Area}

This study was conducted on the Birdwood Tract of the University of Virginia near Charlottesville, in the piedmont region of Virginia (USA) at $38.02^{\circ} \mathrm{N}$ and $78.13^{\circ} \mathrm{W}$. The climate is temperature, with hot, humid summers and mild winters. The average annual temperature is $13.8^{\circ} \mathrm{C}$ and average annual precipitation is $112.6 \mathrm{~cm}$. Most precipitation falls as rain. The study area is an abandoned hayfield which was last disturbed by mowing or grazing in 1967. Vegetation is predominantly the perennial grass, fescue, (Festuca sp.) with patches of blackherry bramble, Rubus allegheniensis (Porter) and Indian currant, Symphoricarpos orbiculatus (Moench), and scattered eastern red cedar, Juniperus virginiana (L.), honey locust, Gleditsia triacanthos (L.), tree-of-Heaven, Ailanthus altissima (Mill.) and persimmon, Diosporos virginiana (L.) trees. Over 1000 meadow voles were tagged in a 3.5 year period from November 1974 to April 1978. Individuals of four other species of small mammals have been trapped on the grids, including one eastern chipmunk, Tamias striatus (L.), two meadow jumping mice, Zapus hudsonius (Zimmermann), about forty short-tailed shrews, Blarina brevicauda (Say), and about 150 white-footed mice, Peromyscus leucopus (Rafinesque).

Two 0.46-ha grids of 100 Fitch live traps (Rose, 1973) each were established in the oldfield, using the methods of Krebs, Keller \& Tamarin (1969). Trapping was initiated on Grid 1 in November 1974 and on Grid 5 in November 1975. Traps were baited with a mixture of cracked corn, milo, and wheat, and were provisioned with hay for nesting material. Traps were set in the evening and checked the following 2 mornings and the intervening afternoon. In the summer months the traps were locked open after the morning trapping period to avoid mortality due to heat. Thus, a typical semi-monthly trapping period consisted of 2 runs during the summer months and 3 runs in the other seasons, Each animal 
was ear-tagged at first capture, and the following data were recorded: location of capture, weight to nearest gram, sex, position of testes in males (scrotal or abdominal); and for females, condition of vagina (perforate or non-perforate), nipple size (small, medium, or large), and condition of pubic symphysis (closed, slightly open, or open).

\section{Enumeration}

Population density was estimated by direct enumeration of the trappable population. Trappability was estimated at each trapping period by comparing the number of voles caught to the number of voles known to be alive. These estimates were summed over 2-month seasonal periods (Table 1). Trappability was highest during late autumn (November-December) and lowest during summer (July-August). Krebs et al. (1969) also reported low trappability of meadow voles during the summer months. Hilborn, Redfield \& Krebs (1976) reported that if

Table 1

Trappability for 2 open-grid populations of Microtus pennsylvanicus, $N$ is the sum of the number known alive during a season. Trappability $(T)$ is the percentage of the animals known alive that were captured.

\begin{tabular}{|c|c|c|c|c|}
\hline Season & & d 1 & & $\begin{array}{l}\text { d } 5 \\
T\end{array}$ \\
\hline Winter (January-February) & 181 & 77.8 & 84 & 66.3 \\
\hline Early Spring (March-April) & 168 & 75.8 & 144 & 85.0 \\
\hline Late Spring (May-June) & 242 & 78.0 & 175 & 75.0 \\
\hline Summer (July-August) & 130 & 52.0 & 112 & 65.0 \\
\hline Early Fall (September-October) & 229 & 78.3 & 145 & 78.7 \\
\hline Late Fall (November-December) & 680 & 85.9 & 318 & 92.0 \\
\hline Average & & 74.6 & & 77.0 \\
\hline
\end{tabular}

the probability of capture for an average individual is above $50 \%$, direct enumeration gives a reliable estimate of population size. With all trappability values $>50 \%$, and all but three $>75 \%$, we consider the density estimates based on the minimum number alive (MNA) method to be reliable. Computer programs of Krebs $(1970 \mathrm{a}$, b) were used to abtain these density estimates for each trapping period.

\section{Criterion for Dispersers}

Dispersal has been studied by trapping animals which move onto grids from which the established populations had been removed (Myers \& Krebs, 1971; Krebs et al., 1976; Tamarin, 1977) and by intercepting animals which leave enclosed populations through exit doors (Gaines et al., 1979; L. Verner and L. Riggs, personal communication). In each case, the population and/or genetic attributes of the removed animals (identified as "dispersers") were compared with those of "residents" from nearby control grids. An alternative to these designs is to monitor dispersal onto open, occupied population grids. Assuming that dispersers can be identified as such, this approach offers the advantage of biological realism, since animals classified as dispersers are moving into or through an established popu- 
lation. Furthermore, since no removal trapping is required, the survival and reproductive performance of these dispersers can be monitored continuously.

Our main problem is establishing a reliable criterion by which dispersers (immigrants) can be identified on the basis of body weight ( $\simeq$ age) at first capture. Operationally, we are best able to identify and establish the origin of those animals which are born on a grid and recruited into the grid population. Young voles make forays from the nest at weights of $9-12 \mathrm{~g}$, but they probably do not venture far before reaching sexual maturity (Van Vleck, 1968). With close spacing of traps $(7.6 \mathrm{~m})$ and frequent (semi-monthly) trapping, we are able to trap young, light-weight animals before they venture far from the maternal home range and, therefore, to correctly identify them as residents. Trapping effort was most intense and trappability was highest during the late spring and late autumn, when most recruitment of young occurred. As a result, about $50 \%$ of the animals classified as residents were captured initially at juvenile body weights $(<22 \mathrm{~g})$.

There is some risk of misclassifying bona fide residents as dispersers for any body-weight criterion above the weight at which juvenile voles first leave the nest. If the weight criterion were very low, say $15 \mathrm{~g}$, there would be a relatively large probability of misclassifying residents as dispersers. Such misclassification would tend to underrepresent residents in the population and to inflate the apparent number of dispersers. On the other hand, if the weight criterion were very high, say $45 \mathrm{~g}$, there would be relatively little risk of misclassifying residents as dispersers, Virtually all residents would be correctly identified as such eventually, but many actual dispersers might mistakenly be identified as residents also. At a high body weight there would be a relatively large probability of inflating the apparent number of residents by the inclusion of dispersers.

To avoid the potential bias associated with either extreme, we selected $30 \mathrm{~g}$ as the a priori criterion for distinguishing between residents and dispersers within a grid population. Individuals weighing $<30 \mathrm{~g}$ at first capture were classified as residents, and those weighing $\geqslant 30 \mathrm{~g}$ were classified as dispersers. This weight was chosen to provide "control" over that portion of the population which we are most confidently able to identify, the residents. If the bona fide residents are identified carefully, we can be confident that "dispersers" are not simply residents that avoided capture until achieving adult body weight. At a weight of $30 \mathrm{~g}$, voles are independent and capable of the long distance travel that a dispersal movement might require. Furthermore, based on autopsies of more than 600 voles collected nearby over a 23 -mo period, we know that voles generally are sexually mature by a body weight of $30 \mathrm{~g}$ (Rose unpubl.).

No animal was classified by residency category (resident or disperser) until after all of the data reported here had been collected and the $30 \mathrm{-g}$ criterion had been selected.

\section{RESULTS}

\section{The 30 -g Criterion}

The validity of the 30 -g criterion for our populations is supported by 3 independent lines of evidence. First, the body weight at which residents disappear from the grid populations provides an independent estimate of the weight at which we might expect to see animals moving 
onto a grid. The distribution of body weights of residents at last capture (Fig. 1) is a slightly skewed normal distribution with a peak between $24 \mathrm{~g}$ and $29 \mathrm{~g}$. More than half $(52 \%)$ of the residents died or emigrated from the grids by the time they reached a weight of $30 \mathrm{~g}$. The average below-30 g resident was captured 2.0 times in 1.5 trapping periods.

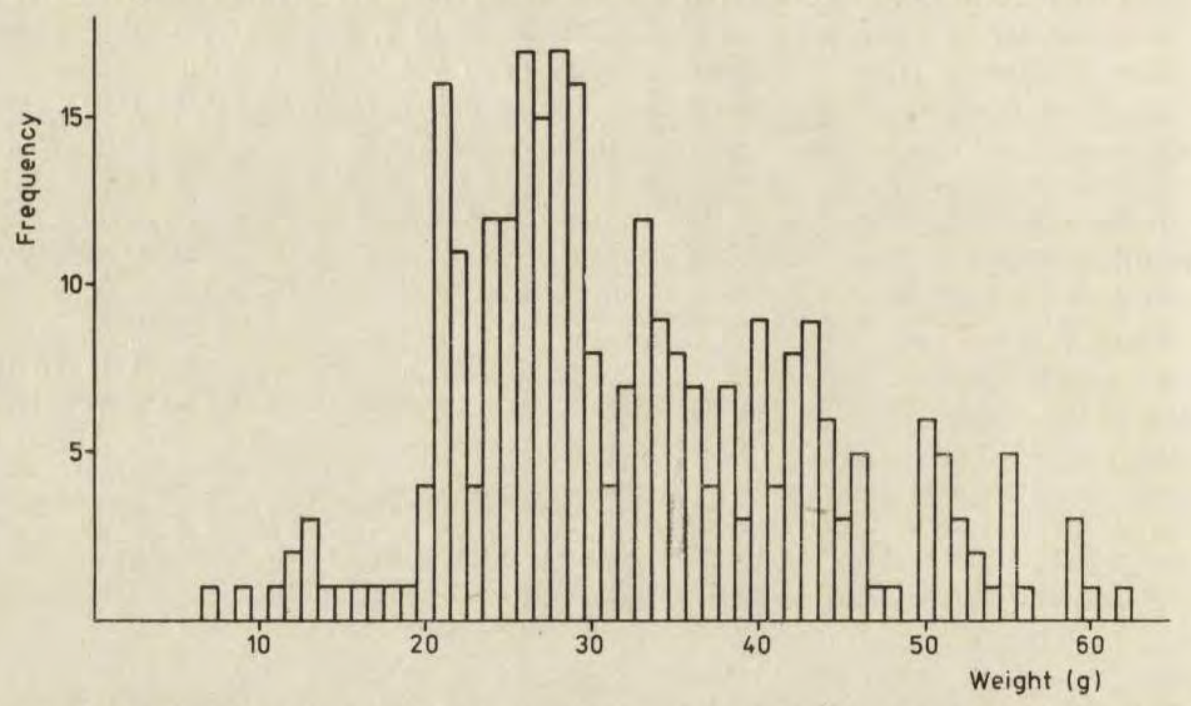

Fig. 1. Body weight (g) of resident meadow voles at final capture on Grids 1 and 5 combined.

Second, for each of the analyses presented below, parallel analyses using the criteria of $33 \mathrm{~g}$ and $36 \mathrm{~g}$ gave similar results. Any criterion above $30 \mathrm{~g}$ must involve greater dilution of the resident category with dispersers. The similarity of the results using a higher weight criterion, therefore, implies that any apparent differences between residents and dispersers must be real. Similarly, the misclassification of any residents which evade capture before reaching $30 \mathrm{~g}$ tends to disguise any real differences between the two residency categories. The 30 -g criterion thus introduces a conservative bias into our comparisons between residency classes.

Finally, our conclusions are strengthened by finding statistically significant differences between dispersers (by definition $\geqslant 30 \mathrm{~g}$ ) and adult residents (those $\geqslant 30 \mathrm{~g}$ ) in comparisons of lifespan, body weight, movement, and reproductive activity.

\section{Population Trends}

The populations on both grids exhibited seasonal fluctuations in density that are characteristic of an annual cycle until 1977, when a steady 
decline diminished densities to about two individuals per grid (Fig. 2). This decline resembles a Type- $H$ decline (Chitty, 1955) in which numbers diminish gradually over one to two years with substantial recovery in each autumn. Because we could make no evaluation of the residency status of newly-tagged voles at the start of the trapping on a grid,

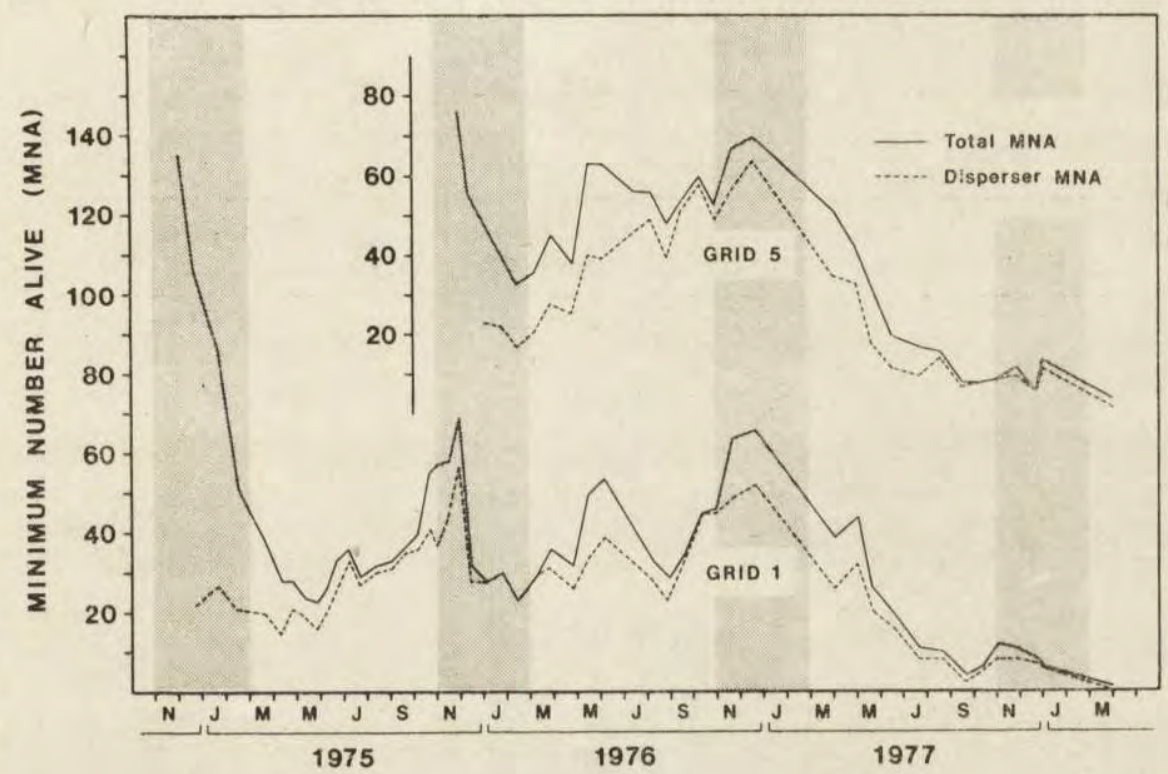

Fig. 2. Population trends of meadow voles on Grids 1 and 5. Disperser MNA includes only those animals weighing $\geqslant 30 \mathrm{~g}$ at first capture. Total MNA includes both resident and disperser animals. Winter months are shaded.

dispersers were not identified until week 6 on Grid 1 (December 1974) and week 60 on Grid 5 (January 1976). Trapping was not conducted between weeks 110 and 125 or between weeks 164 and 177 due to severe weather conditions in January and February, 1977 and 1978. Consequently, adult animals $(\geqslant 30 \mathrm{~g})$ captured for the first time in weeks 125 and 177 also were excluded from all calculations because of uncertain residency status.

Disperser $M N A$ closely parallels total $M N A$ except during the population decline in the winter of $1974-1975$ and during periods of recruitment of young into the trappable population in late autumn and late spring (Fig. 2). In 33 of 50 trapping periods on Grid 1, dispersers comprised at least $75 \%$ of total $M N A$; dispersers constituted a majority of the total population during 46 of 50 trapping periods. In 16 of 29 trapping periods on Grid 5, dispersers comprised at least $75 \%$ of total 
$M N A$, and with one exception, constituted the majority of the population.

\section{Immigration and Recruitment}

As a source of new animals in a grid population, dispersal contributed almost $50 \%$ more individuals than in situ reproduction (Table 2). Fur-

Table 2

Number of newly tagged Microtus pennsylvanicus dispersers and residents observed on Grids 1 and 5 .

\begin{tabular}{cccc}
\hline Grid & $\begin{array}{c}\text { Number of } \\
\text { new dispersers }\end{array}$ & $\begin{array}{c}\text { Number of } \\
\text { new residents }\end{array}$ & $\begin{array}{c}\text { Dispersers } \\
\text { per resident }\end{array}$ \\
\hline 1 & 254 & 173 & 1.47 \\
5 & 157 & 109 & 1.44 \\
\hline
\end{tabular}

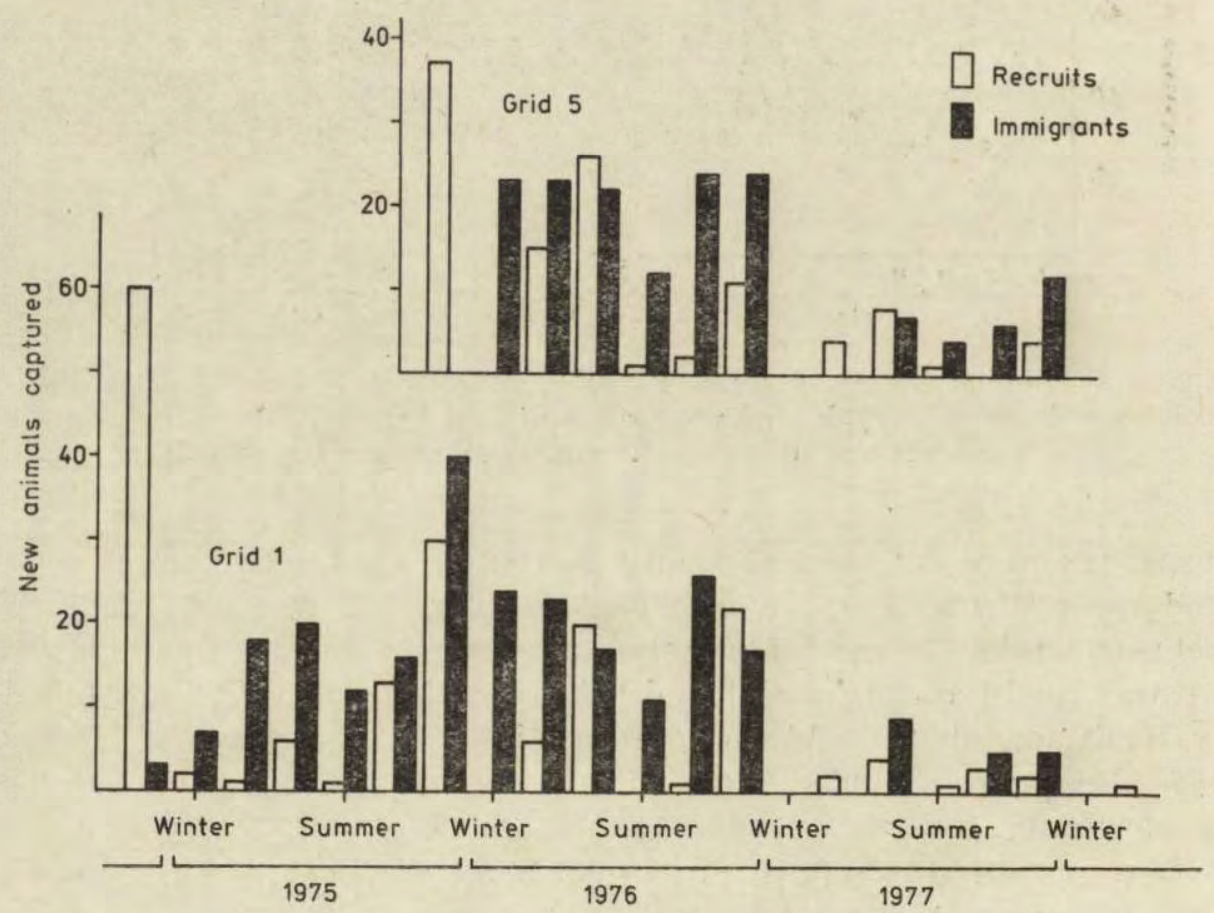

Fig. 3. Number of new recruits and new immigrants (dispersers) captured on Grids 1 and 5. Observations are grouped into the six 2-month seasonal periods listed in Table 1.

thermore, dispersers (immigrants) were added to the population more or less continuously throughout the year, while the recruitment of juveniles 
and subadults occurred almost entirely during brief periods in the late autumn and late spring (Fig. 3). As further evidence of the vagility of these animals, $39 \%$ of the 411 voles classified as dispersers turned out to be transients. These animals were tagged and released on a grid, but were never recaptured.

\section{Density and Dispersal}

The relationship between population density and dispersal was examined in several ways. The correlation between the number of new dispersers in a trapping period and $M N A$ in the previous trapping period is statistically significant on Grid $5(r=0.44, p<0.02)$ but not on Grid 1 $(r=0.19, p>0.17)$. Time-lag dispersal rates varied with population density, at least on Grid 5. The correlation between the number of new dispersers in a trapping period and the number of voles which disappeared since the last previous trapping period was positive but non-significant on both Grid $1(r=0.23, p>0.13)$ and Grid $5(r=0.27, p>0.20)$. Dispersers do not appear to be displacing residents directly.

Dispersal is density-dependent if the proportion of the population which disperses varies with population density (McClenaghan \& Gaines, 1976). This criterion usually translates into an increasing ratio of emigrants to residents as population density increases. With an emphasis on immigration, however, we are actually more concerned with densityrelated resistance to immigration than with density-related emigration. This resistance should produce a negative correlation between immigration rate and population density. We define immigration rate as the ratio of the number of new dispersers (immigrants) in a trapping period to total MNA for that period. There was a negative but non-significant correlation on both Grid $1(r=-0.6, p>0.30)$ and Grid $5(r=-0.35$, $p>0.07$ ). Although it seems reasonable to assume that off-grid (source) density is comparable to on-grid density, it may be somewhat less likely that immigration rate is the mirror image of emigration rate. However, if these densities and rates are comparable we would interpret a negative correlation between immigration rate and population density as evidence for density-dependent dispersal. This interpretation is not supported by the observed (non-significant) correlations. The lack of density-dependent variation in immigration rate is indicated also by the appearance of new dispersers on the grids throughout the annual density cycle (Fig. 3).

\section{Sex Ratios}

Sex ratios (males per female) were calculated for both residents and dispersers. Residents had a ratio of 0.86 on Grid 1 and 1.06 on Grid 5; 
neither ratio differs statistically from $1: 1 \quad\left(\chi_{1}^{2}=0.98, p>0.75 ; \chi_{1}^{2}=0.08\right.$, $p>0.90)$. Dispersers had a ratio of 1.46 on Grid $1\left(\chi_{1}{ }^{2}=9.07, p \leqslant 0.005\right)$ and a ratio of 1.31 on Grid $5\left(\chi_{1}{ }^{2}=2.81, p>0.05\right)$. Males predominated on both grids, although the ratio differs statistically from $1: 1$ only on Grid 1. Although less numerous than males, females still comprised $41.6 \%$ of all dispersers on both grids.

The sex ratios of newly-tagged residents and dispersers also were determined for each trapping period. These ratios were weighted by the number of new individuals captured and summed over all trapping periods for each grid. This weighted sex ratio differs from the overall sex ratio in that a trapping period with a large number of new captures is weighted heavily. The weighted ratios on Grid 1 were 1.06 for residents and 1.90 for dispersers. Similar ratios on Grid 5 were 1.20 and 1.49 , respectively. The weighted sex ratio is greater than the overall sex ratio in all 4 cases, indicating that males predominated in each trapping period, particularly when many new individuals were caught. Both analyses produce the same result: dispersers were more often male than female,

\section{Lifespan}

Residents and dispersers were compared for survival on the basis of lifespan. "Lifespan" is defined here as the interval of time over which an individual is observed as an adult, i.e., the number of weeks between its first capture at $\geqslant 30 \mathrm{~g}$ and its final capture. Individuals captured less than 3 times after reaching $30 \mathrm{~g}$ were excluded from the analysis because they had failed to establish a clear pattern of occupancy on the grids. Voles first captured after week 130 also were excluded because information on their lifespans is incomplete. In summary, then, lifespan comparisons are made only for residents and dispersers which were captured 3 or more times at body weights $\geqslant 30 \mathrm{~g}$.

Three-way analysis of variance was used to test for main effects due to grid $(1,5)$, sex (male, female) and residency category (resident, disperser) (Table 3). Voles on Grid 5 averaged a longer lifespan (24.4 wk) than those on Grid 1 ( $20.3 \mathrm{wk}, p \leqslant 0.02)$. Females averaged a longer lifespan (24.5 wk) than males (19.7 wk, $p \leqslant 0.01$ ). Adult residents and dispersers had comparable lifespans ( 22.3 and $21.7 \mathrm{wk}$, respectively, $p>0.94)$. There were no statistically significant interactions between main effects. Although differences in lifespan were observed between grid populations and between sexes, there was no difference between residents and dispersers. Once dispersers became established on a grid, they survived at least as long as residents. 


\section{Body Weight}

Adult residents ( $\geqslant 30 \mathrm{~g}$ ) and dispersers were compared for robustness on the basis of mean body weight. Visibly pregnant females were excluded from the analysis of body weight. Four-way analysis of variance was used to test for main effects due to grid, sex, residency category and season (winter, early spring, late spring, summer, early autumn, late autumn, Table 4). There was no significant difference between the mean

Table 3

Three-way analysis of variance for lifespan of adult $(\geqslant 30 \mathrm{~g})$ resident and disperser meadow voles.

\begin{tabular}{|c|c|c|c|c|c|}
\hline Grid & Sex & Residency & Lifespan (wk) & SD & $N$ \\
\hline \multirow{4}{*}{1} & \multirow[t]{2}{*}{ Male } & Residents & 18.2 & 10.17 & 16 \\
\hline & & Dispersers & 18.8 & 15.37 & 57 \\
\hline & \multirow[t]{2}{*}{ Female } & Residents & 22.8 & 14.48 & 19 \\
\hline & & Dispersers & 22.5 & 15.44 & 42 \\
\hline \multirow{4}{*}{5} & \multirow[t]{2}{*}{ Male } & Residents & 24.1 & 15.75 & 11 \\
\hline & & Dispersers & 21.2 & 9.83 & 33 \\
\hline & \multirow[t]{2}{*}{ Female } & Residents & 26.7 & 19.06 & 11 \\
\hline & & Dispersers & 30.2 & 17.58 & 25 \\
\hline $\begin{array}{l}\text { Source of } \\
\text { Variation }\end{array}$ & $\begin{array}{l}\text { Sum of } \\
\text { Squares }\end{array}$ & df & $\begin{array}{l}\text { Mean } \\
\text { Square }\end{array}$ & $F$ & $p$ \\
\hline Main Effects & 2535.318 & 3 & 845.106 & 3.922 & 0.009 \\
\hline Grid & 1116.702 & 1 & 1116.702 & 5.182 & 0.024 \\
\hline Sex & 1427.684 & 1 & 1427.684 & 6.625 & 0.011 \\
\hline Residency & 1.421 & 1 & 1.421 & 0.007 & 0.935 \\
\hline Residual & 45253.916 & 210 & 215.495 & & \\
\hline Total & 47789.234 & 213 & 224.363 & & \\
\hline
\end{tabular}

weights of $45.0 \mathrm{~g}$ on Grid 1 and $44.4 \mathrm{~g}$ on Grid $5(p>0.40)$. However, males $(48.0 \mathrm{~g})$ were significantly heavier than females $(40.5 \mathrm{~g}, p \leqslant 0.001)$. Dispersers $(46.5 \mathrm{~g})$ were significantly heavier than adult $(\geqslant 30 \mathrm{~g})$ residents $(40.1 \mathrm{~g}, p \leqslant 0.001)$.

Body weight also varied significantly by season (Table $4, p \leqslant 0.001$ ). Except for a period of steady increase between late autumn 1974 and early autumn 1975, weights of voles on Grid 1 varied seasonally (Fig. 4). Males tended to be heaviest during early autumn and lightest in late spring. Females were heaviest during early spring and lightest during summer and late autumn. Disperser males were heavier than adult residents in 14 of 16 seasons, with the greatest differences occurring in late spring. Disperser females were heavier than adult residents in 15 of 18 
Table 4

Four-way analysis of variance for body weight of adult $(\geqslant 30$ g) resident and disperser meadow voles.

\begin{tabular}{|c|c|c|c|c|c|}
\hline Grid & Sex & Residency & Weight (g) & $\mathrm{SD}$ & $N$ \\
\hline \multirow{4}{*}{1} & Male & Residents & 41.1 & 9.31 & 112 \\
\hline & & Dispersers & 50.1 & 9.24 & 441 \\
\hline & Female & Residents & 37.2 & 8.03 & 134 \\
\hline & & Dispersers & 42.2 & 6.89 & 271 \\
\hline \multirow{4}{*}{5} & Male & Residents & 44.9 & 8.68 & 95 \\
\hline & & Dispersers & 48.4 & 8.49 & 251 \\
\hline & Female & Residents & 37.9 & 5.84 & 85 \\
\hline & & Dispersers & 41.5 & 7.31 & 179 \\
\hline $\begin{array}{l}\text { Source of } \\
\text { Variation }\end{array}$ & $\begin{array}{l}\text { Sum of } \\
\text { Squares }\end{array}$ & df & $\begin{array}{l}\text { Mean } \\
\text { Square }\end{array}$ & $F$ & $p$ \\
\hline Main Effects & 30025.471 & 8 & 3753.184 & 65.568 & 0.001 \\
\hline Grid & 41.895 & 1 & 41.895 & 0.732 & 0.392 \\
\hline Sex & 11561.754 & 1 & 11561.754 & 201.982 & 0.001 \\
\hline Residency & 4367.130 & 1 & 4367.130 & 76.293 & 0.001 \\
\hline Season & 10061.487 & 5 & 2012.297 & 35.155 & 0.001 \\
\hline $\begin{array}{l}\text { 2-way Inter- } \\
\text { actions }\end{array}$ & 6388.214 & 18 & 354.901 & 6.200 & 0.001 \\
\hline Residual & 88208.994 & 1541 & 57.241 & & \\
\hline & 138840.035 & 1567 & 88.602 & & \\
\hline
\end{tabular}

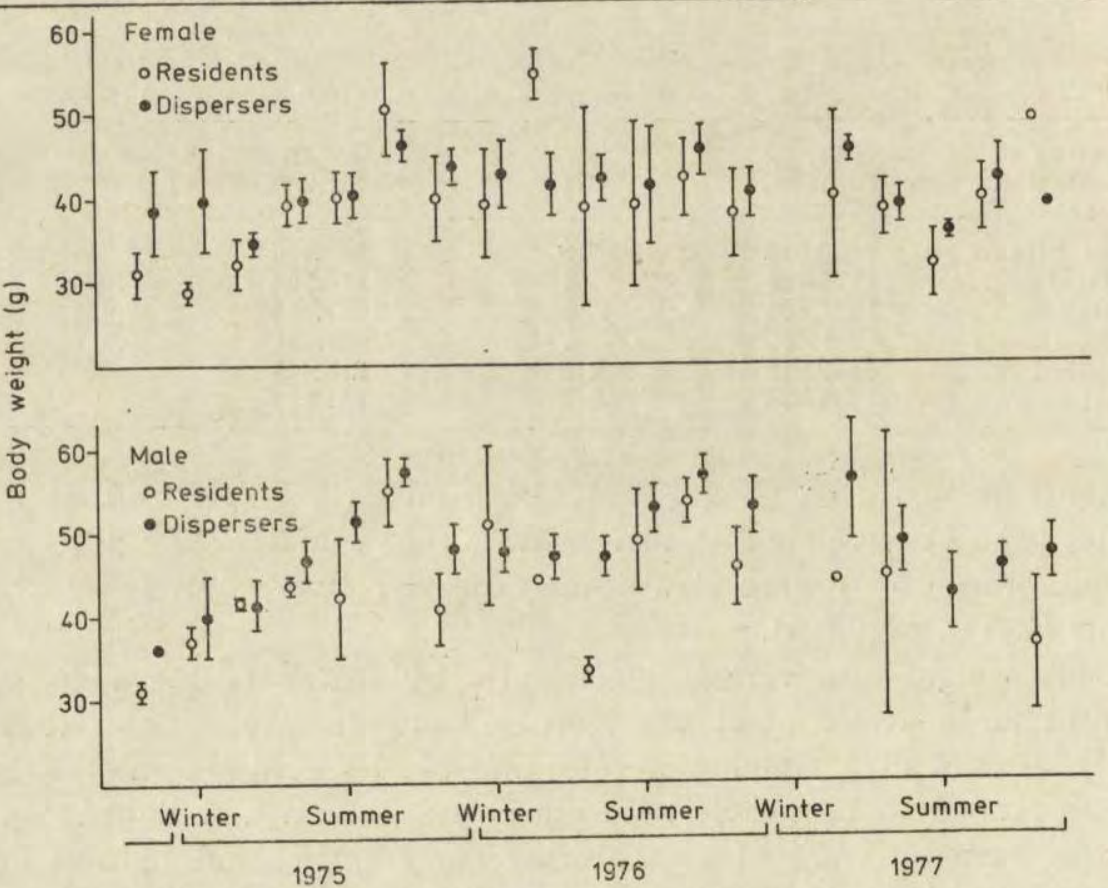

Fig. 4. Body weight $\left(\bar{X} \pm 2 s_{\bar{x}}\right)$ of adult $(\geqslant 30 \mathrm{~g})$ resident and disperser meadow voles on Grid 1. Visibly pregnant females were excluded from this analysis. Observations are grouped into the six 2-month seasonal periods listed in Table 1. 
seasons, with the greatest differences occurring in winter. On Grid 5, voles tended to be heaviest during early autumn and early spring (Fig. 5). Lightest weights were observed in late spring and summer. Disperser males were heavier than adult residents in 6 of 10 seasons, with the greatest difference occurring during the summer. Disperser females were heavier than adult residents in all seasons (10 of 10$)$, with greatest differences occurring in early spring.

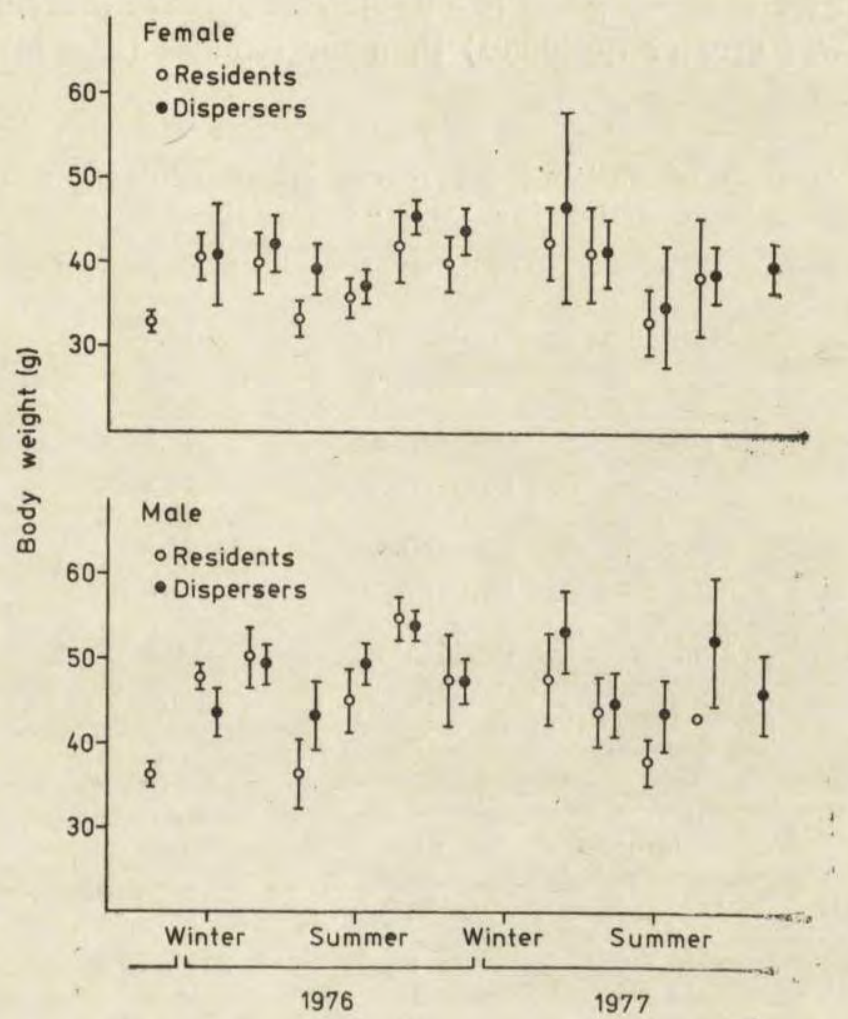

Fig. 5. Body weight $\left(\mathbb{X} \pm 2 s_{\bar{x}}\right)$ of adult $(\geqslant 30$ g) resident and disperser meadow voles on Grid 5. Visibly pregnant females were excluded from this analysis. Observations are grouped into the six 2-month seasonal periods listed in Table 1.

In summary, dispersers were robust individuals, usually as heavy and often significantly heavier than adult residents. For both sexes, mean body weight of both dispersers and residents was usually greatest in early autumn and early spring, just prior to the earliest reproduction in the seasons of greatest reproductive activity. There were two-way interactions of residency with grid and season, but these interactions were unimportant by comparison with the main effects themselves. 


\section{Movement}

To examine the possible relationship between dispersal and intra-grid movement of individuals, the pattern of straight-line movements between traps was analyzed for adult voles ( $\geqslant 30 \mathrm{~g}$ ) recaptured within one trapping period. Four-way analysis of variance was used to test for main effects due to grid, sex, residency category, and season (Table 5). The average movement for adults, $12.4 \mathrm{~m}$ on Grid 1 and $11.6 \mathrm{~m}$ on Grid 5, did not differ between grids $(p>0.50)$. The average movement for males $(13.7 \mathrm{~m})$ was greater $(p \leqslant 0.001)$ than for females $(10.4 \mathrm{~m})$. The average

Table 5

Four-way analysis of variance for movement of adult $(\geqslant 30$ g) resident and disperser meadow voles within 1 trapping period.

\begin{tabular}{|c|c|c|c|c|c|}
\hline Grid & Sex & Residency & Movement & $\mathrm{SD}$ & $N$ \\
\hline \multirow{4}{*}{1} & \multirow[t]{2}{*}{ Male } & Residents & 12.6 & 10.18 & 56 \\
\hline & & Dispersers & 14.5 & 10.33 & 192 \\
\hline & \multirow[t]{2}{*}{ Female } & Residents & 11.3 & 8.51 & 76 \\
\hline & & Dispersers & 10.2 & 7.52 & 145 \\
\hline \multirow{4}{*}{5} & \multirow[t]{2}{*}{ Male } & Residents & 11.1 & 9.74 & 40 \\
\hline & & Dispersers & 13.7 & 12.30 & 109 \\
\hline & \multirow[t]{2}{*}{ Female } & Residents & 9.8 & 7.26 & 64 \\
\hline & & Dispersers & 10.6 & 7.98 & 102 \\
\hline $\begin{array}{l}\text { Source of } \\
\text { Variation }\end{array}$ & $\begin{array}{l}\text { Sum of } \\
\text { Squares }\end{array}$ & df & $\begin{array}{l}\text { Mean } \\
\text { Square }\end{array}$ & $F$ & $p$ \\
\hline Main Effects & 8296.988 & 20 & 414.849 & 4.968 & 0.001 \\
\hline Grid & 38.909 & 1 & 38.909 & 0.466 & 0.495 \\
\hline Sex & 2939.076 & 1 & 2939.076 & 35.198 & 0.001 \\
\hline Residency & 14.853 & 1 & 14.853 & 0.178 & 0.673 \\
\hline Season & 6096.340 & 17 & 358.608 & 4.295 & 0.001 \\
\hline Residual & 63711.345 & 763 & 83.501 & & \\
\hline Total & 72008.334 & 783 & 91.965 & & \\
\hline
\end{tabular}

movements for adult residents $(11.8 \mathrm{~m})$ and dispersers $(12.6 \mathrm{~m})$ were comparable $(p>0.67)$. Distance of movement did vary seasonally $(p \leqslant$ $0.001)$. Males tended to move further during early autumn and early spring; females tended to move further during early and late autumn.

Additional information is available from the 35 tagged animals that moved between Grids 1 and 5 , which were $22.8 \mathrm{~m}$ apart. Twenty-two tagged males, including 7 residents and 15 dispersers, made 32 moves between the grids. Thirteen tagged females, including 5 residents and 
8 dispersers, made 18 moves. Males made 7 round-trips between grids, females 5. Although males appeared to move more often than females, and animals first identified as dispersers moved more than residents, neither difference was statistically significant. At least 7 males and 3 females tagged initially on Grids 1 and 5 were later captured elsewhere at Birdwood, at distances of $200 \mathrm{~m}$ to $400 \mathrm{~m}$ from Grids 1 and 5 .

\section{Reproductive Condition}

The reproductive condition of each individual was determined by examination of external reproductive features, following the criteria of Krebs et al. (1969). Males with scrotal testes were judged to be reproductively active. Females were judged to be reproductively active by having (1) medium to large nipples or (2) open pubic symphysis, or (3)

Table 6

Tests of homogeneity for reproductive condition for adult meadow voles on Grids 1 and $5 . o=$ observed frequencies, $e=$ expected frequencies.

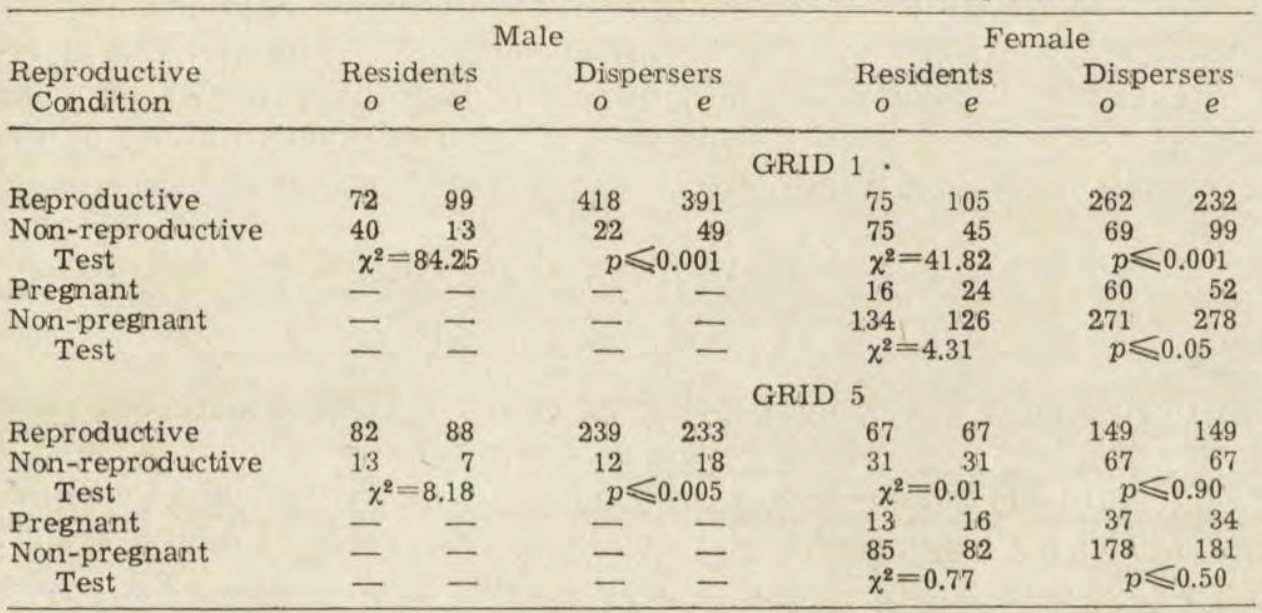

by being visibly pregnant. The number of dispersers (by definition $\geqslant 30 \mathrm{~g}$ ) and adult $(\geqslant 30 \mathrm{~g})$ residents in reproductive condition was tallied for each trapping period, summed over seasons, and weighted according to sample size. Chi-square analysis was used to test for differences in the proportion of reproductively active voles in each residency category. Differences in the proportion of pregnant females were tested in the same manner.

Overall, $64 \%$ of adult $(\geqslant 30 \mathrm{~g})$ resident males and $95 \%$ of disperser males were reproductively active on Grid 1 (Table 6). For females on Grid $1,50 \%$ of adult $(\geqslant 30 \mathrm{~g})$ residents and $79 \%$ of dispersers were reproductively active. Proportionately more dispersers than adult residents of the same sex were in reproductive condition $(p \leqslant 0.001)$. The same Acta Theriologica -2 
effect was observed for adult males on Grid! 5 , where $86 \%$ of residents and $95 \%$ of dispersers were reproductively active $(p \leqslant 0.005)$. However, the adult $(\geqslant 30 \mathrm{~g})$ female residents $(68 \%)$ and dispersers $(69 \%)$ on Grid 5 did not differ $(p>0.90)$. Significantly more disperser females on Grid 1 were pregnant $(18 \%)$ than adult residents $(11 \%, p \leqslant 0.05$, Table 6$)$. On Grid 5, more dispersers were pregnant $(19 \%)$ than adult residents $(13 \%)$, but the difference was not significant $(p>0.50)$.

Reproductive condition of dispersers at first capture also was examined. On Grid 1, $90 \%$ of the newly captured male and $60 \%$ of the female dispersers were reproductively active, and $13 \%$ of the females were visibly pregnant. Similarly, on Grid $590 \%$ of the newly captured disperser males and $54 \%$ of the females were reproductively active, and $13 \%$ of disperser females were pregnant.

In summary, a large percentage of dispersers were in reproductive condition at first capture, and many dispersing females were pregnant. More of the dispersers became reproductively active as they remained on the grids. With the exception of females on Grid 5, proportionately more dispersers were in reproductive condition than adult $(\geqslant 30 \mathrm{~g}) \mathrm{re}-$ sidents of the same sex. Thus, dispersers had the potential to make a greater contribution per individual to the reproductive effort of the population than did residents.

\section{DISCUSSION}

\section{Density and Dispersal}

During most weeks, the populations of Grids 1 and 5 were composed almost entirely of voles that were tagged at body weights of $\geqslant 30 \mathrm{~g}$ (Fig. 2); this is the segment of the populations we have defined as dispersers. The high trappability during all seasons (Table 1) argues against the explanation that a significant proportion of voles escaped detection on the grids. Consequently, we are forced to conclude that the meadow voles in our population were highly mobile. Results of other studies, such as the large number of voles removed from dispersal sinks by several investigators (Myers \& Krebs, 1971; Krebs et al., 1976; Tamarin, 1977) and the earlier studies of colonization of trapped-out habitats by Stickel (1946) and others, also suggest that small mammals are highly mobile. However, the surprising observation is that this high mobility in our populations was achieved with resident meadow voles already occupying the habitat. In the earlier studies, small mammals were responding to, perhaps even detecting, the resources that were available in the trapped-out area. In our study, mobile voles moved into what was often a significant density of voles in place on the grid, yet there ap- 
peared to be little "environmental resistance" to these movements. We know of no other studies that have examined the movement of numerous small mammals into an existing population. Consequently, the high mobility of animals into existing populations and the apparent absence of resistance is a most significant finding.

We observed a significant positive correlation between the number of new dispersers and population density on Grid 5 but not on Grid 1 . Myers \& Krebs (1971) found a positive but non-significant correlation between the number of $M$. pennsylvanicus immigrants to a removal grid and population density on control grids. They observed a significant positive correlation for one population of $M$. ochrogaster. Dispersal seemed to be more prevalent during the phase of population increase for M. pennsylvanicus. Krebs et al. (1976) found that control density and rate of increase together explained $94 \%$ of the variation in the number of $M$. townsendii immigrants to removal grids. Again, colonization of the removal grids was most rapid during periods of population increase on the control grids. Tamarin (1977) found that density on the control grids explained $66 \%$ of the variation in the number of immigrants to removal grids for an island population of $M$. breweri but only $39 \%$ of this variation for mainland populations of $M$. pennsylvanicus. Gaines et al. (1979) also observed a strong, positive correlation between immigration to removal grids and $M$. ochrogaster density on control grids. Thus, the relationship between dispersal and density is variable, but the occurrence of dispersal usually increases with increasing population density. Dispersal may be more pronounced during phases of population increase than in phases of decrease.

Dispersal rate in our vole populations, defined as the ratio of the number of new immigrants in a trapping period to total MNA for that period, was independent of density. This same observation has been reported for populations of M. pennsylvanicus (Myers \& Krebs, 1971; Tamarin, 1977) and $M$. townsendii (Krebs et al., 1976). In these studies, immigrants moved onto grids from which the resident population had been removed, moving along a presumably favorable density gradient. In our study, dispersers moved into established grid populations, with no perceived density gradient. The lack of density-dependence for opengrid populations indicates simply that dispersal is neither halted nor greatly hindered by resident populations, at least within the range of population densities that we observed.

\section{Population Attributes}

Dispersers are more often male $(58.4 \%)$ than female, but adult $(\geqslant 30 \mathrm{~g})$ residents do not deviate from a 1:1 sex ratio. Myers \& Krebs (1971) 
found that dispersal accounted for a higher proportion of the losses of resident males than of females for both $M$. pennsylvanicus and $M$. ochrogaster. Krebs et al. (1976) found an excess of adult male $M$. townsendii on removal grids. Tamarin (1977) observed an excess of males for both residents and dispersers of $M$. breweri. Dispersing $M$. pennsylvanicus included an excess of males in winter and an excess of females in summer. Gaines et al. (1979) found a greater proportion of male $M$. ochrogaster colonizing removal grids, with the deviation from $1: 1$ sex ratios more extreme during phases of increasing density. In burning and fencedenclosure experiments, however, dispersing $M$. ochrogaster were predominantly male. Taken together, these studies indicate that dispersers are more often male than female but that dispersal is not limited to males.

Lifespans of adults were comparable for residents and dispersers (20-40 weeks), and appear to be greater than previously reported for M. pennsylvanicus (Hamilton, 1941; Getz, 1960). Possible explanations for this exceptional longevity include the virtual absence of competing species and the relatively mild winter climate of piedmont Virginia. Krebs (1966) reported the range of average adult life expectation as 8-12 weeks for males and 12-13 weeks for females in expanding populations of $M$. californicus. In declining populations, the values were 3-6 weeks for males and 2-7 weeks for females. Tamarin (1978) reported a range of $12-15$ weeks for both $M$. breweri and $M$. pennsylvanicus in coastal Massachusetts.

For some species, dispersers suffer higher rates of mortality than residents (Errington, 1963; Metzgar, 1967; Kalela \& Koponen, 1970; Carl, 1971). Andrzejewski \& Wrocławek (1961) attributed higher trap mortality for first captures to diminished resistance of dispersers. In contrast, our results indicate that survival (lifespan) is not decreased for dispersers, at least not for dispersers that were captured three or more times. We could not monitor unsuccessful dispersers, i.e., those which died en route or those which moved onto the grids but died before first capture. Nevertheless, the large number of dispersers that was observed indicates that many dispersers did move onto the grids where they survived at least as long as residents.

Dispersers and adult $(\geqslant 30 \mathrm{~g})$ residents had similar-shaped body weight distributions, with males significantly heavier than females. Dispersers were significantly heavier than residents. Because our analysis excluded individuals weighing $<30 \mathrm{~g}$, our results are not directly comparable with previous studies of dispersers onto removal grids.

Adult residents and dispersers exhibited comparable movement within a trapping period. However, there were differences by sex and season. Males moved significantly farther than females. Greatest movement in 
males coincided with the onset of periods of peak breeding activity, in early autumn and early spring. Females exhibited greatest movement during autumn and least movement during late spring, when they may have been nursing young. Tamarin (1977) also found significantly greater movement among males than females of $M$. pennsylvanicus. Greater movement by males also has been reported for other populations of small mammals (e.g., Stickel, 1946; Fitch, 1948; Smith, 1968; Van Vleck, 1968).

Dispersers were reproductively more active than adult $(\geqslant 30 \mathrm{~g})$ residents. More than $60 \%$ of the dispersers were in reproductive condition when they arrived on a grid, and $13 \%$ of the females were judged to be pregnant at this time. The reproductive activity of dispersers continued at a higher rate than that of the adult residents after immigration, indicating successful adjustment to the grids. Myers \& Krebs (1971) found that the testes of adult males were almost always scrotal in both dispersing and resident populations of $M$. pennsylvanicus and $M$. ochrogaster. For subadult males, dispersers were more often in breeding condition than were residents. The proportion of lactating females was lower for dispersers than for residents. Dispersers of both species included a high proportion of young, sexually mature females. Krebs et al. (1976) found that during the breeding season about $10-15 \%$ more subadults of both sexes of $M$. townsendii were in breeding condition on the removal areas than on the control areas. It could not be determined, however, whether these subadults were reproductively active before dispersing to the removal grids. Dispersing voles bred at lower body weights than residents. Tamarin (1977) concluded that dispersing adult and subadult females of both $M$. pennsylvanicus and $M$. breweri had higher reproductive rates than their non-dispersing counterparts. Gaines et al. (1979) observed no differences in breeding activity between resident and disperser males of M. ochrogaster. Among disperser females, adults exhibited a lower, and subadults a higher, incidence of breeding than residents.

The animals identified here as dispersers have succeeded in entering an established population. Furthermore, based on several components of fitness, they appear to be successful individuals. This is in contrast to many studies in which dispersers are described as individuals incapable of occupying a breeding place, or as being driven out of a population of more dominant (and successful) individuals (e.g., Krebs et al., 1969; Krebs et al., 1976; Fairbairn, 1977; Windberg \& Keith, 1976).

\section{Population Dynamies}

Lidicker (1975) recognized two types of dispersal, referred to as saturation and pre-saturation. Saturation dispersal is emigration from a population living at or near carrying capacity. Saturation dispersers have 
the alternative of remaining in the population, probably facing imminent death, or of emigrating, which may provide only slightly improved chances of survival. These animals are likely to be young, old or socially disadvantaged. Pre-saturation dispersal, in contrast, is emigration by individuals which are sensitive to increasing population density or which may have discovered more favorable habitat during exploratory movements. Pre-saturation dispersers are not necessarily in imminent danger of dying. Compared with saturation dispersers, these animals are expected to have a much greater chance of successful relocation.

The attributes of the individual dispersers and the absence of densitydependence suggest that the dispersal reported here is pre-saturation dispersal. Lidicker associates pre-saturation dispersal with colonizing species and those whose feeding styles can affect their future food supplies; M. pennsylvanicus qualifies in both respects (e.g., Christian, 1970; Krebs, Keller \& Tamarin, 1969). Furthermore, pre-saturation dispersers are expected to have a good chance of surviving, of establishing themselves at a new location, and of passing on their genetic make-up to future generations. Each of these attributes accurately describes the dispersens observed in our populations. Tamarin (1977) points out that although saturation dispersal rates should be correlated with population density, pre-saturation dispersal rates should give a poor correlation. Tamarin (1977, p. 1052) further states that "with Microtus pennsylvanicus we have every indication of selective pre-saturation dispersal".

Gaines et al. (1979) hypothesize that pre-saturation dispersal plays a larger role than saturation dispersal in the regulation of microtine populations. They found that populations in fenced enclosures which allowed pre-saturation dispersal (emigration) through exit doors did not undergo interannual cycles. In some cases populations were unable to sustain themselves without periodic introductions of new animals. The immigrants to the Birdwood grids also appear to be a vitalizing input. They were robust, long-lived individuals which had the potential of making a significant contribution to the reproductive effort of the population. Thus, several lines of evidence support the hypothesis that this is an example of pre-saturation dispersal.

Although emigration has been examined as a regulatory mechanism in population biology, immigration has been largely ignored. Bailey (1969) proposed that immigration, acting through disruption of the social organization, might act as a population control mechanism. Although the extent of social organization in populations of small mammals is unclear, some information is available on the influence of immigrants on the social structure of the host population. Andrzejewski, Petrusewicz \& Walkowa (1963) found that newcomers in populations of white mice are ge- 
nerally added to the bottom of an existing social hierarchy, resulting in a minimum of disruption. Studying feral populations of Mus musculus in California, Myers (1974) reported that survival of introduced animals was between 50 and $100 \%$, except during periods of high population density when no animals succeeded in establishing themselves in the population. The proportion of immigrants in the population seemed to influence the success of immigrants in social integration. If the number of immigrants were large, success was more probable than if the number were small (Andrzejewski et al., 1963; Packer \& Lidicker, unpublished results cited in Lidicker, 1975).

The fact that populations in which emigration, but not immigration, was permitted have failed to undergo normal interannual cycles led Gaines et al. (1979) to conclude that immigration is an essential demographic component required for population cycles. The results of our study support this contention by suggesting that immigration is important to a population as a source of new individuals. In our study of dispersers during a type- $H$ population decline, there was no evidence of dispersers displacing residents. However, in some studies (e.g., Healey, 1967 of Peromyscus maniculatus and Ramsey \& Briese, 1971 of Sigmodon hispidus), the influx of large numbers of colonizers did result in a partial exodus of residents. Thus, immigration potentially has dramatic consequences for a host population. Previous studies of dispersal have focused primarily on emigration. Dispersal is a two-way process, however, and to determine its full significance on population processes, emigration and immigration should be studied simultaneously.

Acknowledgements: W. F. Ingogly assisted with portions of the field work. J. H. Porter asisted with portions of the field work and computer analysis of the data. Discussions with W. Z. Lidicker, Jr. and J. J. Murray, Jr. were particularly helpful in clarifying our thoughts on the body-weight criterion. J. A. Bissonette, E. F. Connor, S. F. Fox, A. D. Higgs, P. L. Meserve, J. D. Nichols, and J. H. Porter provided many helpful comments on earlier drafts of the manuscript.

\section{REFERENCES}

1. Andrzejewski R. \& Wroclawek H., 1961: Mortality of small rodents in traps as an indication of the diminished resistance of the migrating part of a population. Bull. Acad. Polon. Sci., Ser. sci. biol., 9: 491-492.

2. Andrzejewski R., Petrusewicz K. \& Walkowa W., 1963: Absorption of newcomers by a population of white mice. Ekol. pol., Ser. A, 11: 223-240.

3. Bailey E. D., 1969: Immigration and emigration as contributory regulators of populations through social disruption. Can. J. Zool., 47: 1213-1215.

4. Carl E., 1971: Population control in arctic ground squirrels. Ecology, 52: $395-413$.

5. Chitty D., 1955: Adverse effects of population density upon the viability of later generations. [In: Cragg, J. B. and Pirie, N. W. (eds.), "The numbers of man and animals"] Oliver and Boyd: $57-67$, London, 
6. Chitty D., 1960: Population processes in the vole and their relevance to general theory. Can. J. Zool., 38: 99-113.

7. Chitty D., 1967: The natural selection of self-regulatory behavior in animal populations. Proc. Ecol. Soc. Aust., 2: 51-78.

8. Christian J. J., 1970: Social subordination, population density, and mammalian evolution. Science, 168: 84-90.

9. Errington P. L., 1963: Muskrat populations. Iowa State University Press: $1-665$. Ames.

10. Fairbairn D. J., 1977: The spring decline in deer mice: death or dispersal? Can. J. Zool., 55: 84-92.

11. Fitch H. S., 1948: Ecology of the California ground squirrel on grazing lands. Amer. Midl. Nat., 39: 513-596.

12. Gaines M. S., Vivas A. M. \& Baker C., 1979: An experimental analysis of dispersal in fluctuating vole populations: demographic parameters. Ecology, 60: $814-828$.

13. Getz L. L., 1960: A population study of the vole, Microtus pennsylvanicus. Amer. Midl. Nat., 64: 392-405.

14. Hamilton W. J., Jr., 1941: Reproduction of the field mouse Microtus pennsylvanicus (Ord). Cornell Univ. Agr. Exp. Sta. Mem. 237. 23 pp.

15. Healey M. C., 1967: Aggression and self-regulation of population size in deer mice. Ecology, 48: 377-392.

16. Hilborn R., Redfield J. A. \& Krebs C. J., 1976: On the reliability of enumeration for mark and recapture census of voles. Can. J. Zool., 54: 1019-1024.

17. Howard W. E., 1960: Innate and environmental dispersal of individual vertebrates. Amer. Midl. Nat., 63: 152-161.

18. Kalela O. \& Koponen T., 1970: Food consumption and movements of the Norwegian lemming in areas characterized by isolated fens. Ann. Zool. Fenn., 7: $80-84$.

19. Krebs C. J., 1966: Demographic changes in fluctuating populations of Microtus californicus. Ecol. Monogr., 36: 239-273.

20. Krebs C. J., 1970a: Computer programs for the analysis of demographic data from small mammal populations. Indiana Univ. Mimeo. $15 \mathrm{pp}$.

21. Krebs C. J., 1970b: Computer programs for the analysis of snap-trapping and autopsy data of small mammals. Indiana Univ. Mimeo. $8 \mathrm{pp}$.

22. Krebs C. J., 1978a: Ecology. The expenimental analysis of distribution and abundance. 2nd ed. Harper and Row: 1-678. New York.

23. Krebs C. J., 1978b: A review of the Chitty hypothesis of population regulation. Can. J. Zool., 56: 2463-2480.

24. Krebs C. J., Keller B. L. \& Tamarin R. H., 1969: Microtus population biology: demographic changes in fluctuating populations of $M$. ochrogaster and $M$. pennsylvanicus in southern Indiana. Ecology, 50: 587-607.

25. Krebs C. J., Gaines M. S., Keller B. L., Myers J. H. \& Tamarin R. H., 1973: Population cycles in small rodents. Science, 179: 35-41.

26. Krebs C. J. \& Myers J. H., 1974: Population cycles in small mammals. Adv. Ecol. Res., 8: 267-399.

27. Krebs C. J., Wingate I., LeDuc J., Redfield J. A., Taitt M. \& Hilborn R., 1976: Microtus population biology: dispersal in fluctuating populations of $M$. townsendii. Can. J, Zool, 54: 79-95. 
28. Lidicker W. Z., Jr., 1962: Emigration as a possible mechanism permitting the regulation of population density below carrying capacity. Amer. Nat., 96: $29-33$.

29. Lidicker W. Z., Jr., 1975: The role of dispersal in the demography of small mammals. [In: Petrusewicz, K., Golley, F. B., \& Ryszkowski, L. (eds). "Small mammals: their productivity and population dynamics"]. Cambridge University Press: 103-128. London.

30. McClenaghan L. R., Jr. \& Gaines M. S., 1976: Density-dependent dispersal in Sigmodon: a critique. J. Mamm., 57: 758-759.

31. Metzgar L. H., 1967: An experimental comparison of screech owl predation on resident and transient white-footed mice (Peromyscus leucopus). J. Mamm., 48: $387-391$.

32. Myers J. H., 1974: Genetic and social structure of feral house mouse populations on Grizzly Island, California. Ecology, 55: 747-759.

33. Myers J. H. \& Krebs C. J., 1971: Genetic, behavioral, and reproductive attributes of dispersing field voles Microtus pennsylvanicus and Microtus ochrogaster. Ecol. Monogr., 41: 53-78.

34. Ramsey P. R. \& Briese L. A., 1971: Effect of immigrants on the spatial structure of a small mammal community. Acta theoriol., 16: 191-202.

35. Rose R. K., 1973: A small mammal live trap. Trans, Kansas Acad. Sci., 76: $14-17$.

36. Smith M. H., 1968: Dispersal of the old-field mouse, Peromyscus polionotus. Bull. Ga. Acad. Sci., 26: 45-51.

37. Stickel L. F., 1946: The source of animals moving into a depopulated area. J. Måmm., 49: 92-103.

38. Tamarin R. H., 1977: Dispersal in island and mainland voles. Ecology, 58: $1310-1321$.

39. Tamarin R. H., 1978: Dispersal, population regulation, and $K$-selection in field mice. Amer. Nat., 112: 545-555.

40. Van Vleck D. B., 1968: Movements of Microtus pennsylvanicus in relation to depopulated areas. J. Mamm., 49: 92-103.

41. Windberg L. A. \& Keith L. B., 1976: Experimental analyses of dispersal in snowshoe hare populations. Can. J. Zool., 54: 2061-2081.

Accepted, 28 January, 1981.

Raymond D. DUESER, Marcia L. WILSON, Robert K. ROSE

WŁASCIWOSCI STRUKTURY MIGRACYJNEJ MICROTUS PENNSYLVANICUS

\section{Streszczenie}

Badano strukturę migracyjną dwóch populacji Microtus pennsylvanicus (Ord., 1815) w środkowej Virginii (USA). Odłowy prowadzono od listopada 1974 do kwietnia 1978 (Tabela 1). Strukturę migracyjną (dispersal) zdefiniowano jako imigrację na powierzchnie zasiedlone już przez osobniki tego gatunku. Napływające norniki wyróżniano od osiadłych na podstawie ciężaru ciala w momencie pierwszego złapania (Ryc. 1; Ryc. 2). Osobniki ważące poniżej $30 \mathrm{~g}$ zaliczano do osiadłych, a ważące 30 lub więcej gramów do imigrantów (dispersals). W oparciu 


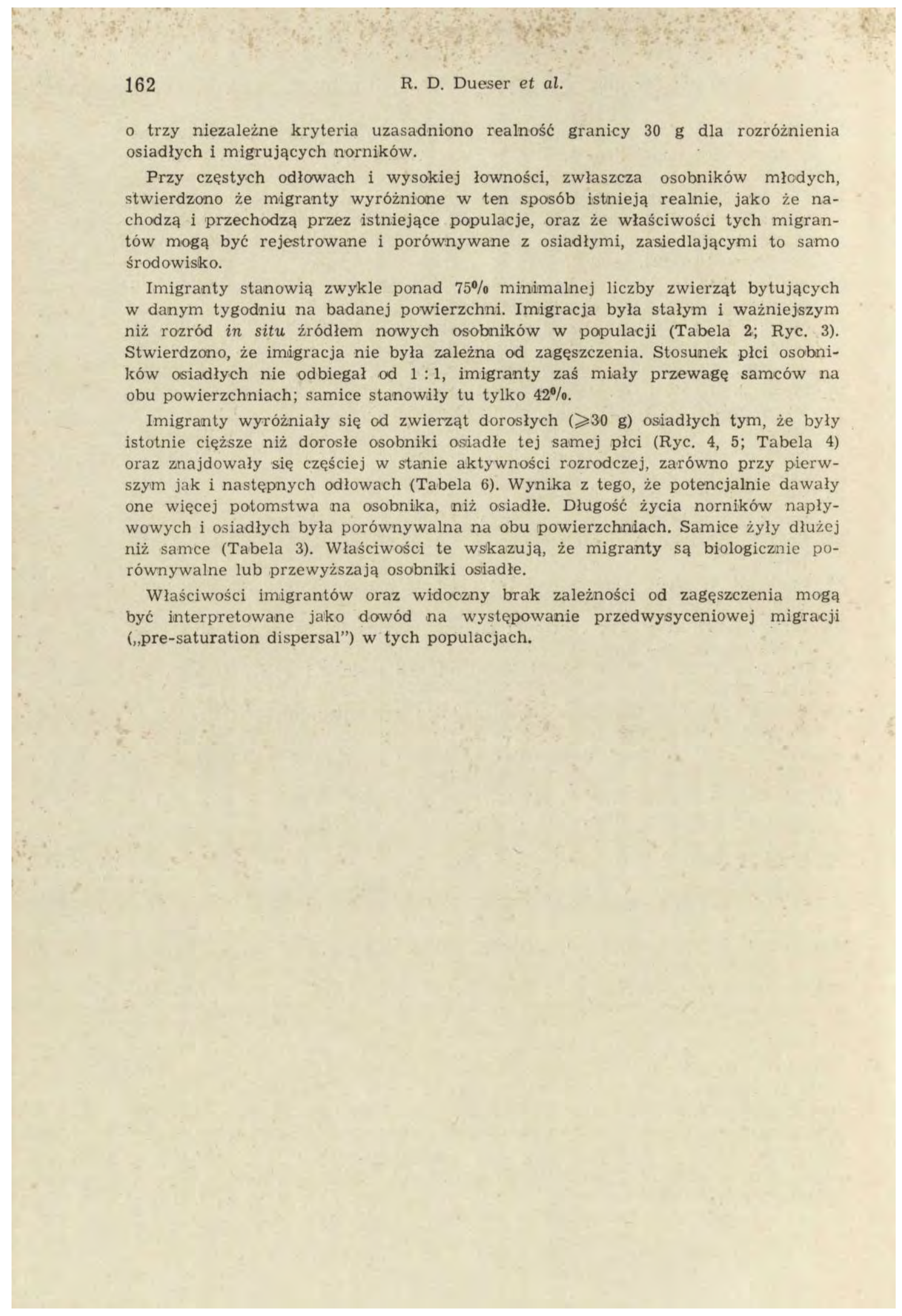

